\title{
Supporting Assessment in Education: E-Assessment Interest in Physics
}

\author{
Maison, Darmaji, Astalini, Dwi Agus Kurniawan*, Sumaryanti, Rahmat Perdana \\ Faculty of Teaching and Education, Jambi University, Indonesia
}

Received September 24, 2019; Revised October 28, 2019; Accepted November 11, 2019

Copyright $\odot 2020$ by authors, all rights reserved. Authors agree that this article remains permanently open access under the terms of the Creative Commons Attribution License 4.0 International License

\begin{abstract}
The purpose of this study is to develop affective assessment of students in physics the form of interests students have using MySQL. There are 3 stages of the method used in this study, namely (1) Development, (2) Implementation, and (3) Evaluation. The subjects involved in this study were 265 students from Batanghari High School with 265 students using purposive sampling techniques. The results of this study are that the validator gives good results regarding the assessment of e-interest in the category given which is very feasible and obtained valid statements of 25 statements with a reliability value of 0.870 . Then students' interest in physics dominated both categories was $54.4 \%$. Student responses when using the e-interest assessment received a good response seen from the attitude of students, who were happy, excited and had a high curiosity towards this E-Assessment. It can be concluded that the e-interest assessment needs to be developed on a large scale.
\end{abstract}

Keywords Assessment, Interest, Physics

\section{Introduction}

The world will respect and change its view of the State from increasing good human resources especially in developed countries that can be seen from the quality of education. It is known that education is the process of acquiring and instilling skills performed by students [1]. In addition, the function of education is very much in developing the potential of students. The potential of this human resource can only be explored and developed effectively through education and learning that is directed and integrated, which is managed in harmony and balance by taking into account the development of the full potential and optimal potential of students [2]. The quality of education is measured on student learning outcomes and student achievement in school. Learning outcomes and learning achievements can be measured through assessment. Assessment will explain developments in the world of education and whether educational success faces global challenges or not.

Assessment in education is very important for teachers to see the development of students cognitive, affective, and psychomotor. Assessments can be carried out for various reasons and intentions that provide certain perspective practices [3]. An important part of the system is the assessment which aims to facilitate mobility and strengthen the quality of education among students [4]. Assessment is like a facility in maintaining the quality of students' learning with information about learning development. Assessment in learning allows students and teachers to get information about developments in learning which is one of the assessment systems[5]. Assessment in perspective is a fundamentally important thing to do in the world of education. Direct assessment or better known as the authentic assessment is the result of a comprehensive learning process of performance. Authentic assessment is a process to describe changes in students after learning which is no longer just the achievement of goals but is an effort to obtain various information on a regular, continuous and comprehensive basis on student learning processes and outcomes[6]. Authentic assessment is divided into one summative assessment. Educators and researchers have recognized that formative assessment is an important element in conducting learning activities to improve student learning effectiveness [7]. Their objective assessment is to determine the level of achievement of the goal - initial learning and the effectiveness of the teaching and learning process [8]. Assessment also has many functions related to gather information to get a general picture of the potential and competencies of students [9]. Assessment must also achieve success because it has a cycle. The success of the ongoing cycle involves identifying results, collecting and analyzing data, discussing, suggesting improvements, implementing 
changes, and reflecting [10].

The purpose of assessment is not only to look at students' cognitive, affective, and psychomotor development but also to look at character assessment, concern not only for knowledge in education, but also aspects of values, such as aspects of values, attitudes, behavior, and other good characters in physics. Character education is a system of instilling character values in the school community that includes components of knowledge, awareness or will, and actions to implement these values, both to Allah SWT (YME), self, others, the environment, and nationality so that they become human [11]. According to psychologists, some basic character values are: love for God and His creation (nature with its contents), responsibility, honesty, respect and courtesy, compassion, caring, cooperation, self-confidence, creation, hard work, never giving up, justice leadership, kindness, humbleness, tolerance, peace and love of unity [12]. From some of the character values presented, the researchers concluded that most of them included one value that underlies the formation of character, namely interest. Interest will encourage students to perform good character in the educational process.

According to [13] that interest is a feeling of being preferred and bound to something or activity, without being told. Interest is an impetus that causes individual attention to be bound to certain objects such as work, lessons, objects, and people [14]. Student interest in learning is needed so that student learning outcomes increase. Interest as a driver in the realization of character education is important because if students do not have an interest, students will not know how to have a character that must be achieved by students not only in learning but also in their potential and talents and interests. In fact, the greater one's interest in learning, that person will tend to pay more attention to the object under study until the desired goal is achieved [15]. For this reason, interest can be measured through assessment of student learning. Look at the tendency of students to prefer learning or lazy to learn.

An interesting character evaluation, in this case, focuses on physics. Physics has an important meaning as a factor in Natural Sciences which can provide opportunities to develop mental strength and thinking power. Physics is also a challenging learning process that involves students dealing with various types of illustrations, such as formulas, calculations, graphical representations, and theoretical understanding at an abstract level [16]. Physics is considered a difficult subject in which many students have at least zero interest [17]. The number of students who think that physics is difficult, especially in connecting concepts and formulas makes researchers interested in seeing students' interests in physics. Researchers began by distributing physics interest questionnaires using a Likert scale. The Likert scale is the most basic psychometric tool and is often used in social science and education research [18]. The Likert scale illustrates the level of agreement or disagreement with the reports contained in the questionnaire of interest in physics learning activities. At first, the researchers used paper sheets to distribute the questionnaire, but it turned out that the paper had shortcomings and was less efficient such as waste, time-consuming, distance traveled, and environmental pollution if it could not be handled properly. For this solution, the development of E-Learning is in line with the development of the industrial revolution 4.0.

E-Learning instructions are delivered on digital devices intended to support learning [19]. Digital-based e-learning can help facilitate learning for teachers and students when learning takes place. This can be considered a teaching and learning process supported by information and communication technology (ICT), which does not have to be a physical meeting of teachers and students, and aims to facilitate flexible activities (anytime and anywhere). Interactive learning and student-centered[20]. E-learning is the newest way to do distance education by distributing material and learning processes through the Internet [21]. E-Learning for computer and android assessment is recommended to be developed because it has many advantages. The general advantages of automated assessment tools for computer programs are speed, availability, consistency, and objectivity of assessment [22]. Therefore, the use of E-Learning can shorten the distance and time so that learning continues to run. In line with the development of E-Learning, E-Assessment must also be developed.

E-interest assessment is the development of assessment in the affective domain of students in the development of the 4.0 industrial revolution in the world of education. The E-Interest Assessment was developed based on the MySQL database server. MySQL is a structure-based query language (SQL) software that is classified as a DBMS (Database Management System), which is Open Source [23]. MySQL strongly follows the flow of information communication and technology. Today's technology is needed especially in facilitating the work of the education world. Compared with manual assessment, E-Assessment with this system has many advantages. Strength includes four main things, namely efficiency, effectiveness, authenticity, and involvement. In terms of efficiency including scheduled implementation, assessment results can be directly reported, automatic responses from the system to respondents. The advantage in terms of effectiveness is direct feedback, can analyze the validity of statements, many types of statements. The strength in terms of authenticity that can be accessed by people and resources, can be designed according to the situation and manage complex tasks. Then in terms of involvement, can use virtual space and review the results of the assessment [24]. 


\section{Materials and Methods}

There are 3 stages [25] in this research model, namely (1) Development, (2) Implementation, (3) Evaluation, which will be explained in more detail as follows.

1. Development Phase, this stage is the stage of developing the E-Assessment questionnaire for students' interest in physics. Indicators of student interest in physics are limited in this questionnaire including six indicators in three aspects of interest, namely cognitive, affective, and psychomotor. In the cognitive aspect there are two indicators, namely 1) Attention in learning and 2) student involvement. Then in the affective aspects there are four indicators namely 3) Feelings of pleasure, 4) Curiosity, and 5) Teaching materials and teacher attitudes. Whereas for the psychomotor aspect there is one indicator, namely 6) Benefits of subjects. The six indicators consist of 30 statements including positive and negative statements of students' daily physics activities and learning processes. Especially statements that contain elements of student interest in physics. Then students can answer the statement with a Likert scale column that has been presented starting from a strongly disagreeing value of 1 , the disagreeing value of 2 , agreeing value of 3 , and strongly agreeing value of 4 , for negative statements strongly disagree is 4 , disagree value of 3 , agreeing value of 2 , and strongly agree is 1. This questionnaire is changed and developed into an e-interest assessment system that uses the MySQL database. Next are the development and manufacture of e-assessments based on flowcharts and storyboards, based on analysis of hardware requirements (software) and software analysis.

2. Implementation Phase, first at this stage a simulation process is carried out on respondents in this case students in small group tests using E-Assessment to find out how students assess E-Assessment students' interests in physics. After learning that the E-Assessment is feasible to use, the next step is to conduct a study on a large group test with the subject being students from grades X to XII from senior high school 6 Batanghari, totaling 265 students. Students can access e-interest assessments with technology-based systems using smartphones or computers.

3. The evaluation phase is carried out to correct weaknesses in students' e-interest assessments in physics lessons with the system after being tested in large groups. The E-assessment is enhanced to connect designers and users directly in terms of assessing students' interest in physics through the website system. The e-interest assessment continues to be improved so that it is appropriate to be used by more respondents in various regions. This step is also intended so that stakeholders can also use the E-Assessment of students' interest in physics with systems.

In this study, there is content validity carried out in consultation with experts (Experts Judgment validation criteria) in accordance with their fields. Validity test in this study involved media experts. Content validity can be seen from the suitability of the product with the demands of the curriculum [26]. The assessment criteria is shown in table 1 below.

Table 1. Validation criteria

\begin{tabular}{|c|c|}
\hline Interval & Category \\
\hline $0.0-25.0$ & Very Inadequate \\
\hline $25.1-50.0$ & Not Feasible \\
\hline $50.1-75.0$ & Worthy \\
\hline $75.1-100.0$ & Very Decent \\
\hline
\end{tabular}

Construct validity, with regard to the construct or structure and psychological characteristics of the aspects to be measured by the instrument. Does the construct explain the differences in individual activities or behavior with regard to the aspect being measured. In this study used 265 samples consisting of classes X, X, and XII senior high school in Jambi City and Muaro Jambi with sampling technique used was purposive sampling technique. Purposive sampling is to choose samples based on certain criteria [27]. In this case the school criteria used are nationally accredited A. Data collection procedures for referring [26], are explained in the figure below:

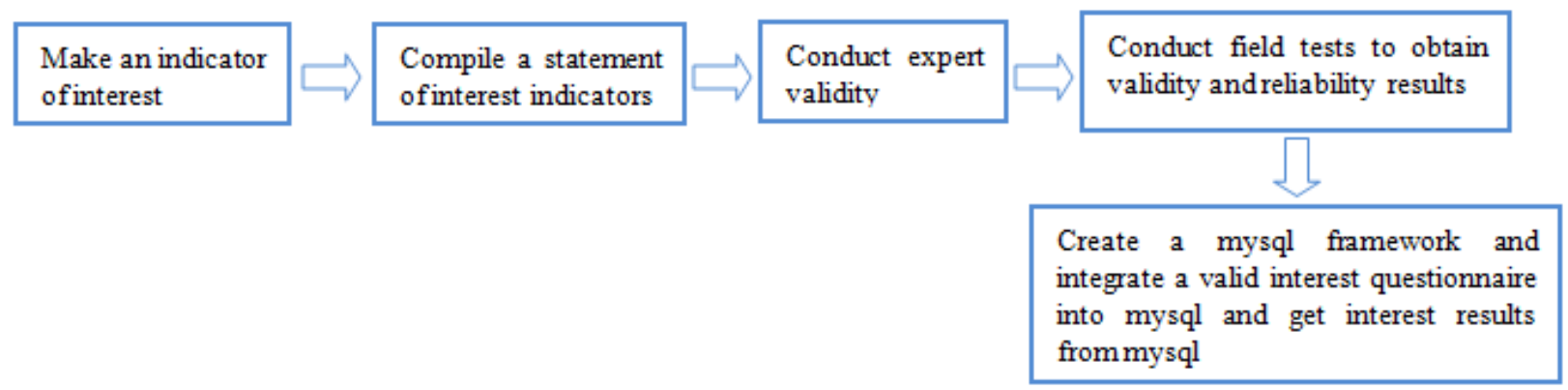

Figure 1. Data Collection 
Based on the picture above, it can be seen that the first activity that must be carried out in the process of collecting data, namely making indicators of students 'interest in physics, then making statements from the indicators that have been made, after the indicators and statements for questionnaire students' interest in physics subjects have been The expert validity test was completed, after the expert validity results were obtained, a field trial was conducted to see the validity and reliability results of the student interest questionnaire in physics. After obtaining a valid statement and the reliability value, then the questionnaire of interest is integrated into MySQL to see the interests of students in physics using the e-interest assessment and a Likert scale of 4 (four) for positive statements Very Disagree having a score of 1, No agree to have a score of 2, Agree to have a score of 3 and Strongly Agree to 4. For negative statements Strongly Agree to have a score of 4, Disagree to have a score of 3, Agree to have a score of 2 and Strongly Agree to have a score of 1 .

\section{Results and Discussion}

The results of this study came from filling out the questionnaire through a program that was entered automatically after being filled out by students as respondents. The data in the form of quantitative data and analyzed using descriptive statistics to see students' interests in physics subjects more clearly. Data processing uses the assistance of IBM SPSS Statistics software.

Based on the results of content validation and constructs that have been carried out, we get good results regarding this e-assessment interest. This assessment is valid due to several factors, which are as follows. First, the validator generally states the statements on the interest assessment instruments are classified as good or very good. Second, the validator chooses the "feasible to use" option on the instrument's feasibility selection. Third, the indicators/descriptors contained in the assessment validity instrument have been developed by taking into account aspects that must be observed in determining the validity of evaluation media, namely content validity and construct validity [28].

E-interest assessment in physics subjects with the MySQL system is one way to improve the quality of assessment in the world of education in student learning. A proper assessment will ensure the provision of appropriate and meaningful feedbacks for students in improving learning [29]. Therefore proper assessment of students such as interests is an important thing must be done to maintain the quality of student learning. For this reason, E-Learning with an e-interest assessment system is the right choice because it is very supportive for teachers in conducting assessments.

The e-interest assessment database system of students in physics subjects uses the MySQL database. The MySQL database server is a program that can store large amounts of information in an unorganized format that is easily accessed through programming languages such as PHP [30]. Relational systems such as MySQL store data in tabular form and use a structured query language (SQL) to access data [31]. The many features of MySQL make this database a good database system. The advantage is in terms of speed, increased stability, and being able to handle tens of thousands of tables and billions of data lines so quickly and smoothly. The advantage of the MySQL storage engine is that it is a transaction-safe storage engine that allows the rollback of data. In addition, there are also many functions in MySQL [32].

Another advantage of using MySQL is online orientation. This is the most widely used database system, having native integration in software-related systems, such as PHP processors [33]. The many advantages of MySQL are one of the reasons for applying to the e-interest assessment system. With the existence of MySQL in the e-interest assessment program, it can simplify the amount of information entered by students to find out students' interests in physics. Data from research results can be seen more clearly in the following table.

\subsection{Expert Validation}

Based on the results of the validation done by media experts, it was found that the e-interest assessment was very good and feasible to be used as an assessment in measuring student interest in learning, especially in the eyes of physics, and greatly facilitated teachers and students in assessing themselves without having to use guidelines based on paper. Shown by the results in the table below:

Table 2. Results from expert validation of e-interest assessments

\begin{tabular}{|c|c|c|c|}
\hline No & Aspect & Feasibility Level & Category \\
\hline 1 & Theory & 87.3 & \multirow{2}{*}{ Very Decent } \\
\hline 2 & Display & 89.6 & \\
\hline 3 & Language & 88.5 & \\
\hline
\end{tabular}

From the results of the validation done by the experts, it was found that the very feasible category for the material aspect with a level of eligibility was 87.3 , the display aspect was 89.6 with a very feasible category and the Language aspect had a feasibility level of 88.5 , which meant it was very feasible. Therefore, based on the results of the validation done by the expert, it can be concluded that the e-interest assessment used to measure student interest is very feasible and good to use.

From the results of the validity that have been done by experts, the researchers then conducted a field test to get the results of their validity and reliability, which can be seen in table 3 . 
Table 3. Results of questionnaire statements of students' interest in physics

\begin{tabular}{|c|c|c|c|c|c|c|}
\hline \multirow{2}{*}{ Indicator } & \multicolumn{2}{|c|}{ Statement } & \multicolumn{3}{|c|}{ Valid Statement } & \multirow{2}{*}{ Total } \\
\cline { 2 - 6 } & Positive & Negative & & Positive & Negative & \\
\cline { 2 - 6 } & $1,3,20$ & $11,28,29$ & 6 & $1,3,20$ & 11 & 3 \\
\hline Attention in learning & $7,17,21$ & $5,26,27$ & 6 & $7,17,21$ & 5 & 4 \\
\hline Student involvement & $6,18,25$ & 13,24 & 5 & $6,18,25$ & 13,24 & 5 \\
\hline Feelings of pleasure & $10,22,23$ & 9,12 & 5 & $10,22,23$ & 9,12 & 5 \\
\hline Curiosity & 4,14 & 16,19 & 4 & 4,14 & 16,19 & 4 \\
\hline Teaching materials and attitude & $8,15,22$ & 2,30 & 5 & $8,15,22$ & 2 & 4 \\
\hline Benefits of subjects Total & & 30 & \multicolumn{2}{|c|}{ Total } & 25 \\
\hline
\end{tabular}

After conducting a test that aims to see the validity of each statement of student interest in physics, there are 25 valid statements obtained from 6 indicators, which initially amounted to 30 statements from 6 indicators. The results of the reliability value can be seen in table 4 .

Table 4. Reliability of student questionnaire interest in physics subjects

\begin{tabular}{|c|c|}
\hline Cronbach Alpha & N of Items \\
\hline .870 & 30 \\
\hline
\end{tabular}

From table 4, it can be seen that this interest questionnaire has a Cronbach alpha value of 0.870 , which is greater than 0.70. Therefore, it can be concluded that the e-interest assessment instrument in physics subjects is said to be reliable. From 30 statement items, there are 25 valid and reliable items.

\subsection{E-Assessment Student Interest in Physics Students}

The e-assessment of students' interest in physics in this study uses the system that is being developed. This e-interest assessment was conducted on 265 high school students in Indonesia. E-Assessment Results Students' interests in physics are as follows:

Table 5. Assessment E-Interest in Senior High School

\begin{tabular}{|c|c|c|c|c|c|c|c|}
\hline \multicolumn{3}{|c|}{ Category } & \multirow{2}{*}{ Mean } & \multirow{2}{*}{ Median } & \multirow{2}{*}{ Min } & \multirow{2}{*}{$\operatorname{Max}$} & \multirow{2}{*}{$\%$} \\
\hline Interval & Attitude & Total & & & & & \\
\hline $34-44.5$ & Very not good & 15 & \multirow{4}{*}{56} & \multirow{4}{*}{56} & \multirow{4}{*}{34} & \multirow{4}{*}{76} & 5.7 \\
\hline $44.6-55$ & Not good & 106 & & & & & 40.0 \\
\hline $55.1-65.5$ & Well & 121 & & & & & 45.7 \\
\hline $65.6-76$ & Very good & 23 & & & & & 8.7 \\
\hline \multicolumn{2}{|c|}{ TOTAL } & 265 & & & & & 100 \\
\hline
\end{tabular}

Table 5, explains that students have a good interest category for physics as much as $45.7 \%$ with a total of 121 students and an excellent interest category of $8.7 \%$ with as many as 23 students. So students who have a good interest of $54.4 \%$ are the dominant results, while students who are categorized as very interesting are $5.7 \%$ with 15 students. Student interest categories are not good at 40\% with 106 students. The average and median scores in the study of student interest in physics are 56. It can be said that dominant students have a good interest in the pursuit of physics in high schools in Indonesia. With good dominant results, an electronic based assessment is needed to see students' interest in learning physics. 


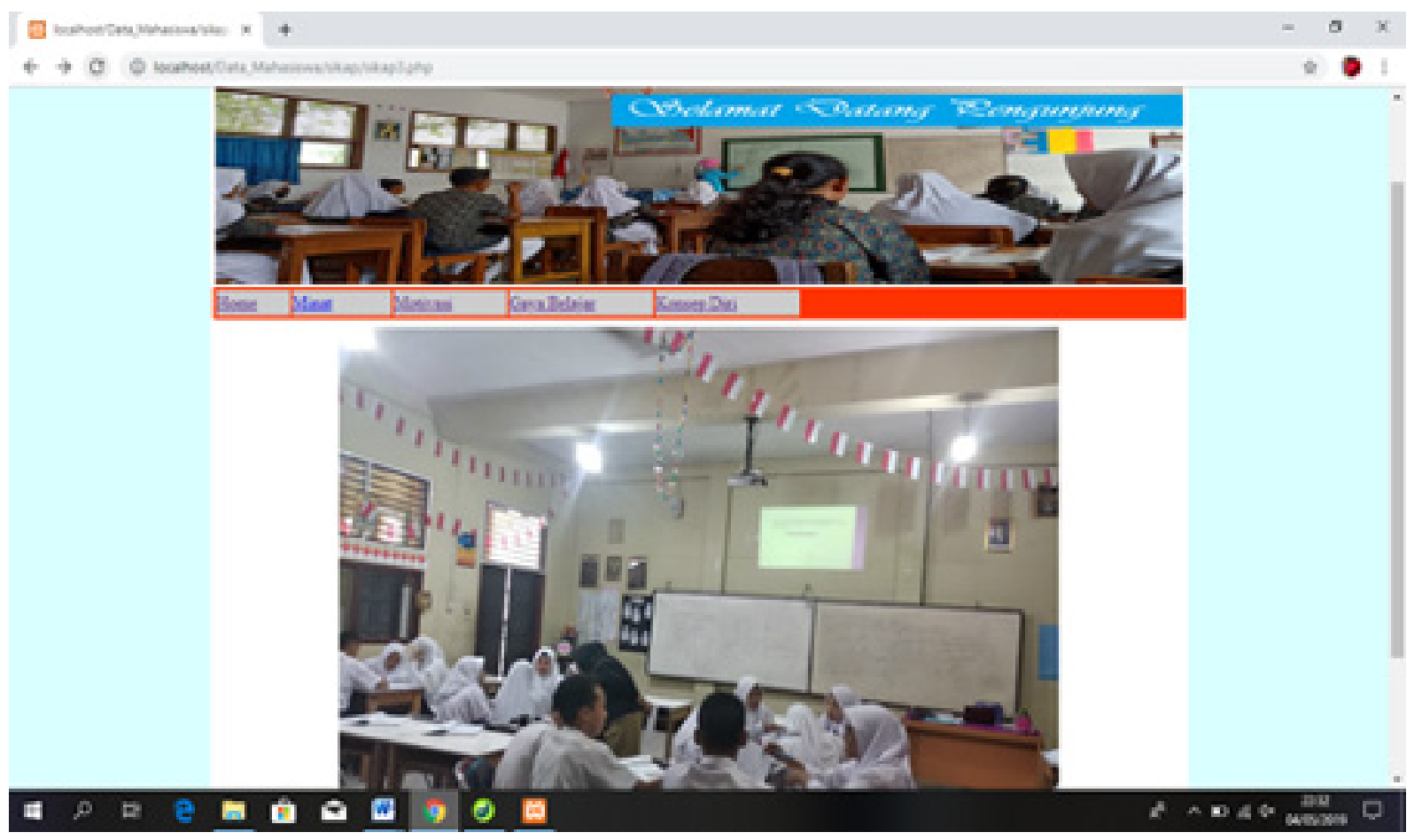

Figure 2. Front Page E-Interest Assessment System in Physics Subjects

\subsubsection{Student Interest E-Assessment of Physics-Based Subject}

Figure 1 shows a web appearance development assessment of student interest in physics using the system "MySQL. This e-interest assessment becomes the starting page when respondents use the e-interest assessment. On the screen, there are two class conditions of respondents, where one picture shows that students are learning and the other shows students form discussion groups in the learning process of physics Students respond well and look enthusiastic with e-interest assessment programs Students look enthusiastic and happy using communication and internet-based assessment systems that have never been used in schools before In addition, this system can help facilitate the work of teachers and stakeholders to find out about the latest developments in students related to their interest in learning physics in the classroom Students and teacher's interests indicate that assessment needs need to be improved and developed in the world of education. Interest is very helpful in assessing effectively and efficiently.

\subsubsection{E-assessments: Interest in Physics Subjects}

The e-assessment is based on a questionnaire instrument that is entered using coding and developed by the system. This questionnaire was processed using the
MySQL system which aims to create an assessment tool for students' interests in physics. The form of the E-Assessment page display when the respondent clicks on the 'flower' subtitle that is as shown below.

Figure 3 and figure 4 show the e-interest Assessment display. In the system there are filling in names, classes, instructions to fill in and statements that can be filled out by students by clicking on the column of strongly disagree, disagree, agree, or strongly agree. The statement is about the activities and study habits related to students' interests in physics. Initially, the statement was presented on "paper" which was later changed to E-Assessment in the programming language (coding). Because in general, filling in the questionnaire manually and conventionally has a number of disadvantages such as the distribution of the questionnaire which takes a long time and more energy must be expended. Likewise, the process of entering data into a computer also means a lot of time and energy. Solutions to these problems can be overcome by technology and computers can change systems that are still computerized or computerized in the form of e-assessments [34]; [35]; [36]; [37]. Therefore e-interest assessment appears to help and facilitate assessment because it is based on information systems and technology that are carried out by stakeholders with students. 


\begin{tabular}{|c|c|c|c|c|c|}
\hline \multirow{2}{*}{ No. } & \multirow{2}{*}{ Penyataan } & \multicolumn{4}{|c|}{ Jawaban } \\
\hline & & TS & KS & $\mathbf{S}$ & SS \\
\hline 1 & Saya mendengarkan dengan baik ketika guru sedang menjelaskan materi pelajaran fisika & O & O & O & 0 \\
\hline 2 & Saya malas mengulangi pembelajaran fisika yang saya dapatkan dikelas ketika saya tiba di rumah & O & $O$ & O & O \\
\hline 3 & $\begin{array}{l}\text { Saya memahami semua penjelasan guru baik dari awal sampai akhir dalam proses pembelajaran fisika yang } \\
\text { berlangsung }\end{array}$ & O & 0 & $\mathrm{O}$ & $\mathrm{O}$ \\
\hline 4 & Materi pembelajaran fisika yang saya pelajari sangat berbobot & O & 0 & 0 & 0 \\
\hline 5 & Saya tidak suka memberikan jawaban jika ada pertanyaan saat proses pembelajaran fisika berlangsung & O & O & O &  \\
\hline 6 & Saya merasa tertarik dengan materimateri pelajaran fisika yang diajarkan & O & O & O & O \\
\hline 7 & Saya mengajukan banyak pertanyaan saat proses pembelajaran fisika berlangsung & O & 0 & O & 0 \\
\hline 8 & Setiap materi yang diajarkan oleh guru saya dalam pembelajaran fisika sangat bermanfaat & O & $\odot$ & O & O \\
\hline 9 & Saya mencontek pekerjaan kawan saya saat diberikan tugas oleh guru fisika & O & 0 & 0 & 0 \\
\hline 10 & Saya mempelajari sesuatu hal baru dalam pelajaran fisika & O & $\odot$ & O & $\mathrm{O}$ \\
\hline 11 & Saya tidak memperhatikan saat pembelajaran fisika sedang berlangsung & O & 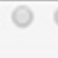 & 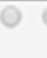 & 0 \\
\hline 12 & Bagi Saya fisika merupakan pembelajaran yang hanya mempelajari tentang rumus saja & O & O & ○ & O \\
\hline 13 & Saya tidak bersemangat dalam mengikuti pelajaran fisika yang diajarkan & O & $\mathrm{O}$ & $\mathrm{O}$ & 0 \\
\hline 14 & metode pembelajaran yang diberikan oleh guru saya menambah frekuensi dalam belajar fisika & O & O & O & O \\
\hline 15 & Saya ingin lebih mendalami pembelajaran fisika & O & O & O & O \\
\hline
\end{tabular}

Figure 3. Assessment E-Interest in phyics of valid statement

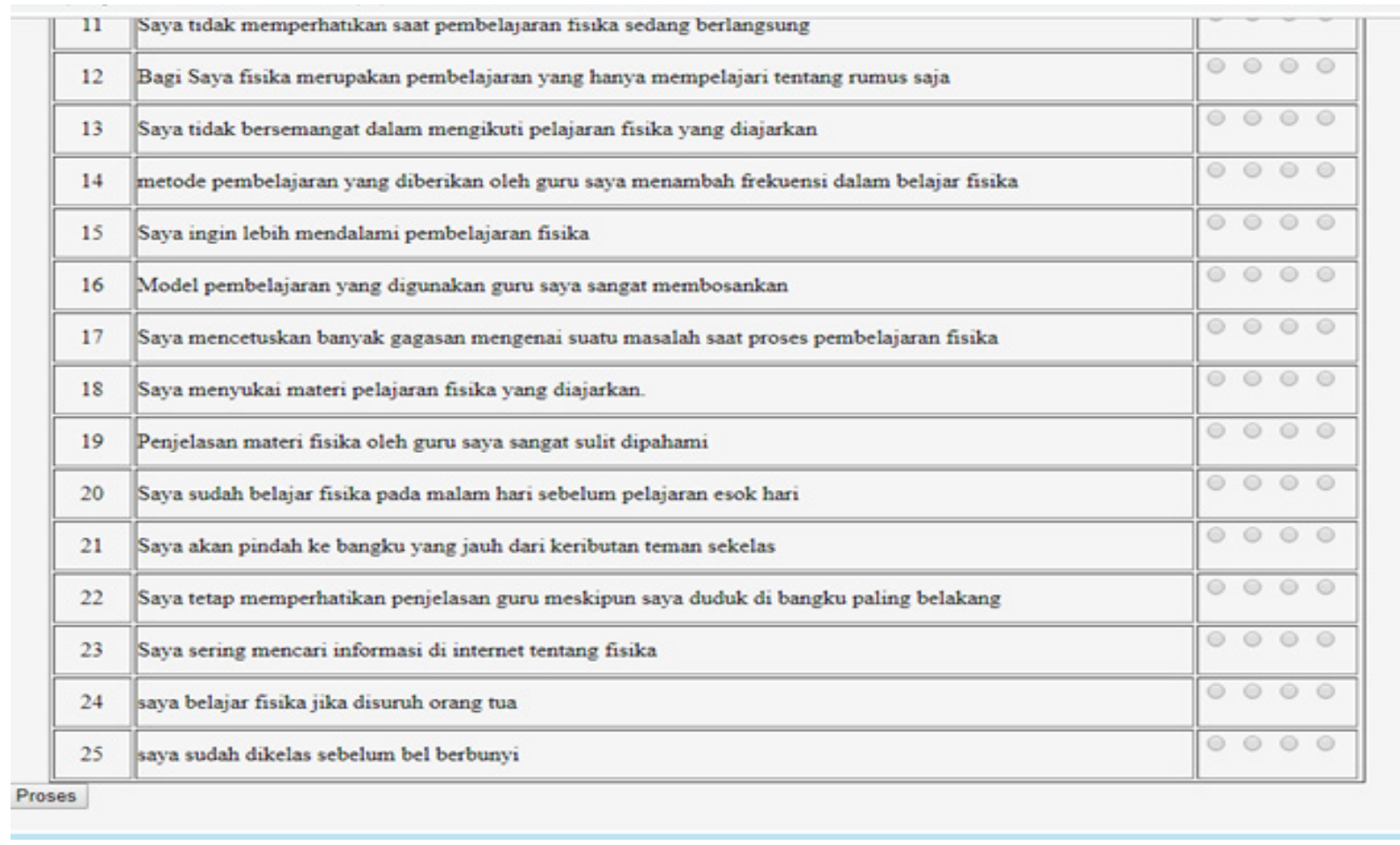

Figure 4. Assessment E-Interest in phyics of valid statement 


\section{GRAFIK MINAT BELAJAR FISIKA}

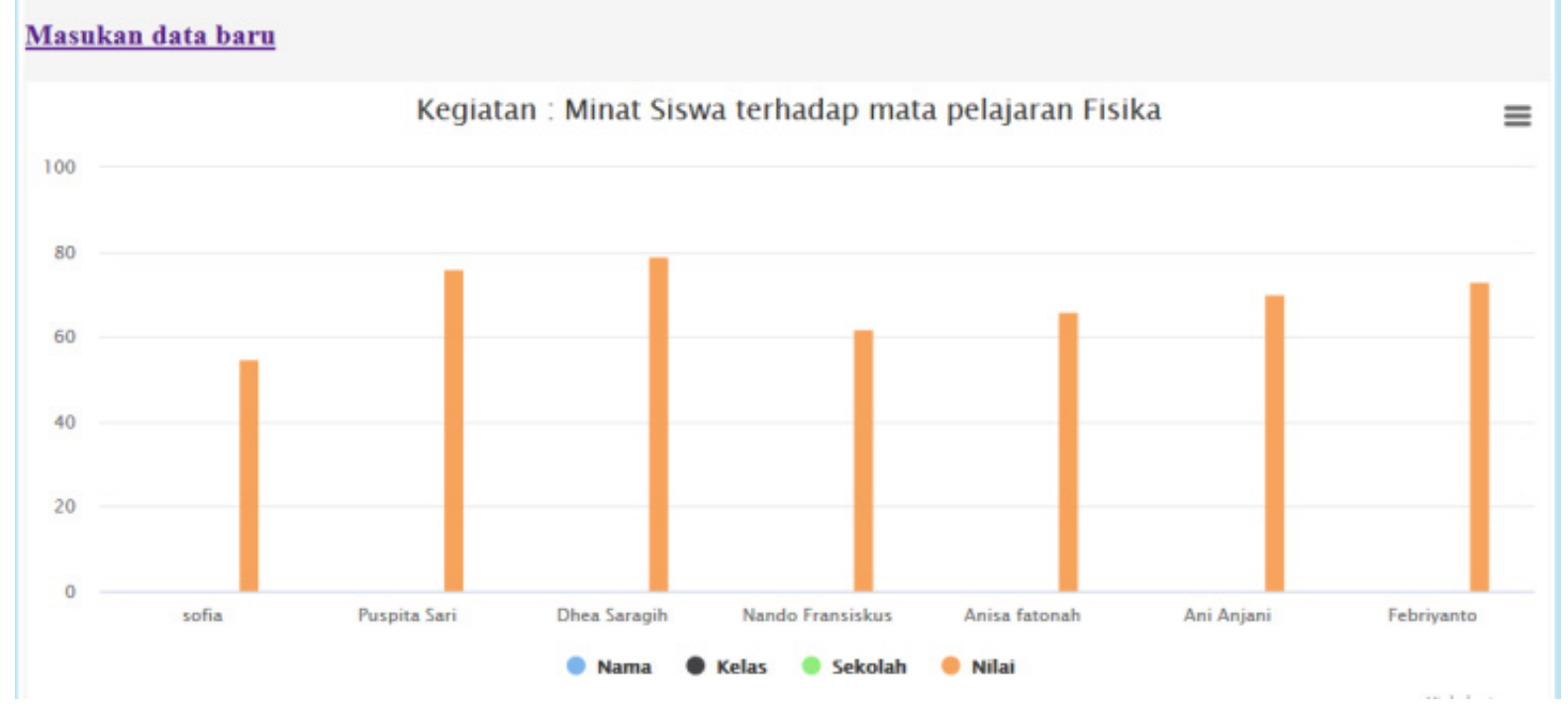

Figure 5. Graph of E-Assessment Data Results

Figure 5 shows the implications of filling out the questionnaire conducted by the respondent. The result of the data from filling out the E-Assessment is a bar graph that provides an explanation of the level of student interest in learning physics based on the Likert scale chosen by students. The results of the data are stored in a MySQL database. So, after we enter the data into the e-interest assessment system, it will be stored in a MySQL database and displayed as shown above.

\section{Conclusions}

E-Assessment's interest in physics can facilitate access because it is made from MySQL database-based software that has a small hard drive and memory footprint. Instrument of interest in physics has been tested by experts in their fields and obtained valid statements of 25 statements with a reliability value of 0.870 . The results demonstrated that the e-interest assessment in physics showed dominant results in the good category, namely $54.4 \%$ of 265 high school students in Indonesia. The responses from students were quite satisfying with enthusiasm and high curiosity when using this E-Assessment. This shows that a larger scale e-interest assessment system needs to be developed to facilitate teachers or students in evaluating themselves because it is in line with the industrial revolution 4.0.

\section{Acknowledgements}

The researcher would like to thank the headmaster of senior high school $1 \& 6$ Muaro Jambi, and the head of senior high school $1 \& 6$ Jambi City, the teachers and of course the students who have been willing to be sampled in this study, I thank you, and all parties involved I say thank you for it.

\section{REFERENCES}

[1] Wood, K. (2011). Education is Basic. New York: Taylor \& Francis Group.

[2] Dharmayana, I Wayan Masrun, Amitya Kumara and Yapsir G Wirawan (2012). Involvement of Students (Student Engagement) as Mediator Emotional Competence and Academic Achievement. Journal of Psychology. 39 (1): 76 $-94$

[3] Baden-Fuller, C., \& Haefliger, S. (2013). Business models and technological innovation. Long range planning, 46(6), 419-426.

[4] Stödberg, Ulf. (2012). A research review of e-assessment. Assessment \& Evaluation in Higher Education. 37 (5): 591-604

[5] Birenbaum, M. (2006). A learning Integrated Assessment System. Educational Research Review 1: 61-67. doi: 10.1016/j.edurev.2006.01.001

[6] Taufina. (2009). Authentic Assessment in Learning Indonesian in Low Class Sd. Pedagogy. Educational Scientific Journal. 9(1), 113-120

[7] Bell, B., \& Cowie, B. (2001). The characteristics of formative assessment in science education. Science Education, 85, 536-553.

[8] Newton, Paul E. (2007). Clarifying the purposes of educational assessment. Assessment in Education, 14(2): 149-170.

[9] Khamida, Mighfar., Ely Rudyatmi, Wulan Christijanti. 
(2014). Utilization of Twitter Social Networking as an Online Self-Assessment to Support Students' Readiness in Learning Digestive Systems. Unnes Journal of Biology Education 3 (2): 180-185

[10] Buzzetto, Nicole A and Ayodele Julius Alade. (2006). Best Practices in e-assessment. Journal of Information Technology Education. 5: 251-269

[11] Citra, Y. (2012). Implementation of Character Education in Learning. Special Education Scientific Journal. 1(1): 237-249

[12] Setiawati, L., \& Pohan, L. D. (2017, September). Brief Cognitive Behavior Therapy for College Students with Depression Symptoms: A Case Study. In 1st International Conference on Intervention and Applied Psychology (ICIAP 2017). Atlantis Press.

[13] Djaali. (2013). Educational Psychology. Jakarta: PT Bumi Aksara

[14] Jahja, Yudrik. (2015). Developmental Psychology. Jakarta: Prenadamedia Group

[15] Wati, R., Nyeneng, I, D. P., \& Suyanto, E. (2017). The Influence of Interest in Learning against Physics Learning Outcomes in a Guided Inquiry Learning Model. Physics Learning Journal. 5 (2): 21-32

[16] Sitotaw, B., \& Tadele, K. (2016). Student Attitude toward Physics in Primary and Secondary Schools of Dire Dawa City Administration, Ethiopia. World Journal of Educational Research and Reviews. 2 (2): 014-021.

[17] Jufriadi, A., Ayu, H. D., Pratiw, H.Y. (2018). Developing E-Scaffolding Integrated with E-Assessment to Improve Student's Mastery of Concept. Advances in Social Science, Education and Humanities Research, vol. 287

[18] Joshi, A., Kale, S., Chandel, S., \& Pal, D. K. (2015). Likert scale: Explored and explained. British Journal of Applied Science \& Technology, 7(4), 396.

[19] Al-Yahya, M., George, R., \& Alfaries, A. (2015). Ontologies in E-Learning: Review of the Literature International Journal of Software Engineering and Its Applications. 9(2): 67-84.

http://dx.doi.org/10.14257/ijseia.2015.9.2.07

[20] Martínez - Caro, E. (2011). Factors affecting effectiveness in e - learning: An analysis in production management courses. Computer Applications in Engineering Education, 19(3), 572-581.

[21] Ardito, C. Et al. (2006). An approach to usability evaluation of e-learning applications. Univ Access Inf Soc (2006) 4: 270-283. DOI 10.1007 / s10209-005-0008-6

[22] Amelung, M., Krieger, K., \& Sner, d. R. (2011). As A Service E-Assessment. Ieee Transactions On Learning Technologies. 4 (2): 162-174

[23] Pranata, D., Hamdani., \& Dyna M, K. (2015). Designing a Computer Scientific Journal Website (Case Study: Mulawarman University Computer Science Study Program). Informatics Journal Mulawarman. 10 (2): 25-29

[24] Permadi, T., Mustangin, and Walida, S. E. (2015). Development of Attitude E-Assessment in High School Mathematics Learning. Journal of Mathematics Education.

\section{1(2): $118-126$}

[25] Branch, M, B. (2009). Instructional Design: The ADDIE Approach. USA: University Of Georgia.

[26] Ivers, K. S., \& Barron, A. E. (2002). Multimedia Project in Education: Designing, Producing, and Assessing. USA: Libraries Unlimited.

[27] Kerlinger, F. N. (2014). Foundations of behavioral research. Yogyakarta: Gadjah Mada University Press.

[28] Nieveen, N. (1999). Prototyping to reach product quality. In Design approaches and tools in education and training (pp. 125-135). Springer, Dordrecht.

[29] Jusuf, R., Sopandi, W., Wulan, A. R., \& Sa'ud, U. S. (2019). Strengthening Teacher Competency through ICARE Approach to Improve Literacy Assessment of Science Creative Thinking. International Journal of Learning, Teaching and Educational Research, 18(7).

[30] Yank, k. (2009). Your Own Build Database Driven Web Site Using Php \& Mysql. Australia: Sitepoint.

[31] Damodaran B, Dipina., Shirin Salim and Surekha Marium Vargese. (2016). Performance Evaluation Of Mysql And Mongodb Databases. International Journal on Cybernetics \& Informatics. 5(2): 387-394

[32] Silalahi, M., \& Wahyudi, D. (2018). Comparison of Performance of Mongodb and Mysql Databases in Web-Based Multimedia File Applications. CBIS JOURNAL. 6 ( 1 ): $63-78$

[33] Stroe, Ion-Sorin. (2011). MySQL databases as part of the Online Business, using a platform based on Linux. Journal Systems Database. 2 (3)

[34] Sahidu, H., Gunawan, Indriaturrahmi, Astutik, F. (2017). Design of E-Assessment System in Physics Learning in LPTK [E-Assessment System Design in Physics Learning at LPTK]. Journal of Physics and Technology Education. 3 (2): $265-270$

[35] Birenbaum, M. (2006). A learning Integrated Assessment System. Educational Research Review 1: 61-67. doi: 10.1016 / j.edurev.2006.01.001

[36] Astalini., Kurniawan, D. A., Sulistiyo, U., Perdana, R., Susbiyanto, S. (2019). E-Assessment Motivation in Physics Subjects for Senior High School. International Journal of Online and Biomedical Engineering (iJOE). 15(9), 4-15.

[37] Astalini., Darmaji., Kurniawan, W., Khairul, A., \& Kurniawan, D. A. (2019) Effectivenes of Using E-module and E-Assessment. International Journal of Interactive Mobile (IJIM), 13(9), 21-39. 